\title{
Comparative immunological studies in liver diseases
}

\author{
GYÖRGY SZÉCSEY, GYÖRGY DÓBIÁS, AND ERNÖ KEREKES \\ From the University Third Medical Clinic and the Department of Clinical Pathology, \\ The Postgraduate School of Medicine, Budapest
}

SYNOPSIS By fractionation of human liver tissue, nuclear, mitochondrial, and connective tissue antigens were prepared. According to the results of serological tests, in conditions associated with substantial damage to the hepatic parenchyma, antibodies reacting with the nuclear and mitochondrial antigens are produced that show practically no reaction with the connective tissue antigen. It is advisable to use fractionated, connective tissue-free antigens for the demonstration of antibodies formed against liver tissue. The use of antigens containing connective tissue may lead to non-specific reactions.

It is known that in the various diseases of the liver factors with the properties of antibody reacting with liver tissue can be demonstrated in serum, and they were first demonstrated in hepatitis, in the different forms of cirrhosis of the liver, and in visceral lupus erythematosus by the complement-fixation test (Eaton, Murphy, and Hanford, 1944; Findlay, Martin, and Mitchell, 1944; Miles, 1946; Bjørneboe and Krag, 1947; Gajdusek, 1958; Mackay, 1958; Mackay and Gajdusek, 1958; Muschel, Simonton, Wells, and Fife, 1961; Wiedermann, Doerner, and Miescher, 1964), by the precipitation test (Olitzki and Bernkopf, 1945; Scheiffarth and Berg, 1950; Vorlaender, 1952; Scheiffarth, Frenger, and Brichzy, 1955; Vorlaender, 1955), as well as by the antihuman globulin consumption test (Rissel, Steffen, and Wewalka, 1957; Dausset and Marchal, 1959; Wiedermann et al., 1964). The antibodies active against the nuclei of cells could also be demonstrated by immunocytochemical methods (Kühn and Weinreich, 1964; Bouchier, Rhodes, and Sherlock, 1964) in chronic diseases of the liver. According to recent data (Wiedermann et al., 1964) the anti-liver 'cytoplasmic' antibodies are not organ and species specific.

In earlier work, in which the above antibodies were demonstrated partly by the antihuman globulin consumption test (Szécsey, Dóbiás, and Porgányi, $1963,1964)$ and partly by the thrombocyte consumption test described by one of us (Dóbiás, 1963a and b), it was found that both reactions yielded positive results first in cases of acute hepatitis with a tendency to poor healing, in chronic hepatitis, as well as in cirrhosis of the liver, in $70 \%$ of the cases tested. In

Received for publication 12 November 1965. cases of acute hepatitis healing without complications in six weeks the positive sera amounted to $30 \%$ and in cases of infection of the biliary ducts to $20 \%$. Both tests yielded positive results much more frequently in the cases of inflammation caused by bacteria or viruses (bronchial pneumonia, staphylococcal sepsis, follicular tonsillitis, influenza, infectious mononucleosis) than in the control group. We have been unable to put forward an explanation. It has been assumed that the 'non-specific' reaction would be due to an eventual lesion in liver produced by the infections mentioned or to lack of homogeneity of the antigen used in the tests.

In the present investigations we wanted to find out against which subcellular components of the liver tissue the antibodies demonstrable are directed, and we have tried to obtain information as to the factors responsible for the 'non-specific' positive reactions.

\section{MATERIALS AND METHODS}

ANTIGENS The antigens for serological tests were prepared from viscera of young people killed in accidents within six hours of death.

Liver tissue homogenate Liver tissue was homogenized essentially according to the method of Schneider and Hogeboom (1950). The liver was pressed through a wire mesh of about $1 \mathrm{~mm}$. pore size, and the stroma, which remained on the mesh and contained mainly connective tissue elements, was placed for half a minute in a Waring blender, afterwards being washed with physiological $\mathrm{NaCl}$ solution, so that the shreds of parenchyma adhering to the stroma could be virtually eliminated. The connective tissue fibres that remained were then homogenized for another 10 minutes in a Waring blender and afterwards washed seven times with physiological 
$\mathrm{NaCl}$ at $+4^{\circ} \mathrm{C}$. The snow-white fibrous material thus obtained is called the connective tissue fraction. The liver mash passed through the mesh was suspended in $0.25 \mathrm{M}$ sucrose solution of neutral reaction containing also $\mathrm{K}^{+}$ ions, and the liver cells were homogenized at $+4^{\circ} \mathrm{C}$. in a Potter homogenizator. The homogenate was centrifuged at $+4^{\circ} \mathrm{C}$. for 12 minutes at $700 \mathrm{~g}$, the sediment was washed once with $0.25 \mathrm{M}$ sucrose solution, and centrifuged again for 12 minutes at $700 \mathrm{~g}$. The sediment thus obtained is called the nuclear fraction. The supernatants were pooled and centrifuged for 70 minutes at 7,000 g. The sediment was the mitochondrial fraction. It was determined histologically that it contained no nuclei. The nuclear and mitochondrial fractions were then washed seven times with a $1 \%$ solution of $\mathrm{NaCl}$ at $+4^{\circ} \mathrm{C}$. to remove sucrose solution, serum proteins, and dissolved liver cell proteins that interfere with the serological tests. Until use, the different liver tissue fractions were stored at $-20^{\circ} \mathrm{C}$.

The connective tissue fraction is liver connective tissue, practically free from liver cells or liver cellular components; the nuclear fraction is composed mainly of cell nuclei but contains also the finer elements of the connective tissue structure of the liver that passed through the mesh, as well as part of the mitochondria; the mitochondrial fraction could be considered to be homogeneous, although it did not contain the total quantity of mitochondria, only the heavy or big ones settling out at the relatively low centrifuge speed.

Heart homogenate Ventricular muscle was homogenized for four minutes at $4^{\circ} \mathrm{C}$. in a Waring blender, then washed seven times with physiological $\mathrm{NaCl}$ solution at $+4^{\circ} \mathrm{C}$. Until used, the sediment was stored at $-20^{\circ} \mathrm{C}$.

SEROLOGICAL TESTS The antihuman-globulin and the thrombocyte consumption tests were carried out as described in previous papers (Szécsey et al., 1963; Dóbiás, 1963a and b; Szécsey et al., 1964).

\section{RESULTS AND DISCUSSION}

To demonstrate the antibodies, we used parallel antihuman globulin and thrombocyte consumptioß tests. The antigens were the mitochondrial, nucleae and connective tissue fractions prepared from humain livers. Blood was obtained from patients tested foufe to eight times during their stay at the hospital an $\Phi$ the sera were stored at $-20^{\circ} \mathrm{C}$. without preservative until tested. The results of the tests involving the use of different antigens (liver tissue fractions), as well as the distribution of the patients according to clinicas diagnosis, are presented in Table I.

In agreement with the data in the literature (Eaton et al., 1944; Findlay et al., 1944; Olitzki and Bernkopf, 1945; Miles, 1946; Bjørneboe and Krag. 1947; Schneider and Hogeboom, 1950; Scheiffart and Berg, 1950; Vorlaender, 1952; Scheiffarth et al 1955; Vorlaender, 1955; Rissel et al., 1957; Gajdusek $\xi_{\infty}^{6}$ 1958; Mackay, 1958; Mackay and Gajdusek, 1958. Dausset and Marchal, 1959; Muschel et al., 196kù Dóbiás, 1963a and b; Szécsey et al., 1963; Bouchief et al., 1964; Kühn ard Weinreich, 1964; Szécsey et al., 1964; Wiedermann et al., 1964), our results have shown that in certain disease of the liver serum factors of autoantibody nature may be producedo and can be demonstrated in those conditionf associated with a significant lesion in the parenchymà The positive results showed about the same frequenco with the nuclear and mitochondrial fractions However, our investigations failed to decide whetheg the positive reactions obtained with nuclear fraction were due to a mitochondrial contamination of the antigen or to antinuclear antibodies. Table $\overrightarrow{\vec{d}}$ indicates that the sera tested yielded positive results with the connective tissue fraction in a very smati percentage of cases only. It is likely therefore that in diseases of the liver the antibody type serum factors are produced against the elements of the parer.chyme in the first place.

Comparison of the results of the antihumag

TABLE I

RESULTS OF TESTS USING DIFFERENT LIVER TISSUE FRACTIONS

Thrombocyte Consumption Test

Diagnosis

\begin{tabular}{lll} 
Thrombocyte Consumption Test \\
\hline $\begin{array}{l}\text { Liver Mito- } \\
\text { chondrial } \\
\text { Fraction }\end{array}$ & $\begin{array}{l}\text { Liver Nuclear } \\
\text { Fraction }\end{array}$ & $\begin{array}{l}\text { Liver Connective } \\
\text { Tissue Fraction }\end{array}$ \\
$\begin{array}{ll}\text { No. of Positive } \\
\text { Cases }\end{array}$ & $\begin{array}{l}\text { No. of Positive } \\
\text { Cases }\end{array}$ & $\begin{array}{l}\text { No. of Positive } \\
\text { Cases }\end{array}$
\end{tabular}

\begin{tabular}{l} 
Antihuman Globulin \\
Liver Mito- \\
Fraction \\
\hline $\begin{array}{l}\text { No. of Positive } \\
\text { Cases }\end{array}$
\end{tabular}

Consumption Test Liver Nuclear Liver Connective Fraction Tissue Fraction No. of Positive No. of Positive Cases Cases

Protracted acute hepatitis ${ }^{1}$, chronic hepatitis, cirrhosis of the liver Acute hepatitis ${ }^{2}$ Obstructive jaundice, cholecystitis Other internal diseases Healthy persons

$\begin{array}{rrrrrrr}15 & 8 & 17 & 9 & 12 & 1 & 14 \\ 14 & 4 & 14 & 3 & 12 & 0 & 12 \\ 3 & 1 & 5 & 0 & 4 & 0 & 3 \\ 5 & 0 & 4 & 0 & 4 & 1^{3} & 4 \\ 16 & 0 & 15 & 0 & 16 & 0 & 15\end{array}$

${ }^{1}$ Time in hospital $>6$ weeks

Time in hospital $<6$ weeks.

${ }^{3}$ Ulcus ventriculi. 
globulin and thrombocyte consumption tests shows that the former yields positive results more often in cases of liver disease, but the reaction was positive in about $10 \%$ of the control cases also. On the other hand, the thrombocyte consumption test yielded no positive results in the sera of patients suffering from other medical conditions or of normal subjects. Our comparative results tend to indicate that the antihuman globulin consumption test is more sensitive but it is also less specific. Of the two reactions, the thrombocyte consumption test yields more reliable results in the search for serum factors reacting with liver tissue.

In our previous investigations (Dóbiás, 1963a and b; Szécsey et al., 1964) we found that the thrombocyte consumption test yielded positive results in $40 \%$ of the cases of 'mixed' infections, when non-fractionated liver antigen was used. It was surmised that in the conditions damaging mesenchymal elements, e.g., carditis, furunculosis hydradenitis, serum factors of the nature of an antibody reacting with connective tissue antigen are produced that react with the connective tissue elements in the non-fractionated liver antigen. This hypothesis is supported by the results of the thrombocyte consumption tests presented in Table II. They indicate that in cases of bacterial infections the damage caused by inflammation to the connective tissue may also give rise to the production of such antibodies as can react with mesenchymal elements, irrespective of organ specificity. It is likely that the production of these antibodies was responsible in our previous studies (Dóbiás, 1963a and b; Szécsey et al., $1963,1964)$ for the high percentage of 'non-specific' positive reactions in the group of mixed infections, when liver antigen containing larger quantities of connective tissue elements was used. Essentially the same conclusion has been drawn by Osztovics and Szutrély (1960) from the results of the tests in which sera from children suffering from carditis were tested with heart homogenate or fibroblast culture antigen.

It often occurred in our studies that on repeated testing the results of the serological reactions varied. A previously positive reaction turned negative usually when the patient had been treated with glycocorticoids. The effect of steroid treatment on the results of the serological tests is shown in Table III. To demonstrate serum factors of antibody nature we used liver mitochondrial and nuclear fraction antigens in the antihuman globulin and thrombocyte consumption tests. As the results in Table III indicate, positive reactions were by about $50 \%$ less common during prednisolone therapy (20 to $30 \mathrm{mg}$. daily) than before or after such treatment, in agreement with our earlier observations (Dóbiás, 1963a and b; Szécsey et al., 1963, 1964). The differences are presumably not due to an inhibition of antibody production, because the previously positive reactions turned negative in the majority of cases, generally within a day or two, in response to treatment, and turned positive again

TABLE II

RESULTS OF THROMBOCYTE CONSUMPTION TESTS

Thrombocyte Consumption Test

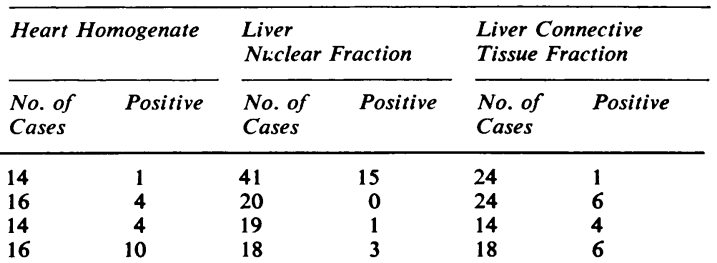

Acute, protracted acute and chronic hepatitis, cirrhosis of the liver Chronic furunculosis, hydradenitis In adults with high AST values ${ }^{2}$ Rheumatic carditis in children

${ }^{2}$ Suffering neither from carditis nor from rheumatic fever.

TABLE III

EFFECT OF STEROID TREATMENT ON RESULTS OF CONSUMPTION TESTS

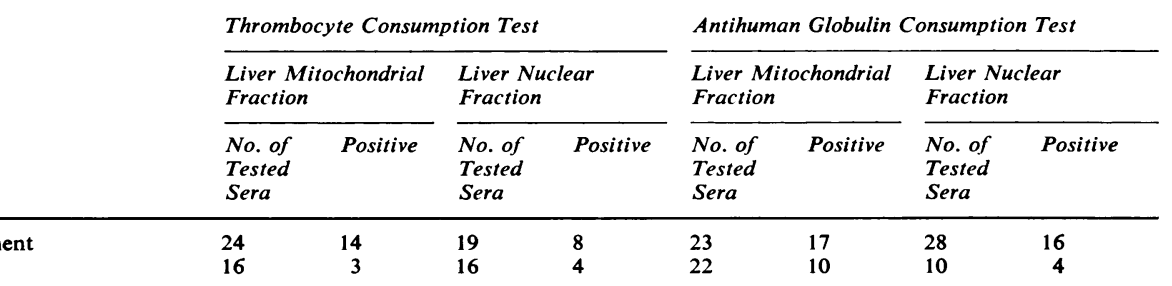

Before or after steroid treatment During steroid treatment 
shortly after treatment had been discontinued. Considering that the half life of $7 \mathrm{~S}$ gamma globulin is 14 days in children and 23 days in adults, the serological reactions ought to have turned negative after a much longer period of time if an inhibition of antibody production had been responsible for the change. We think it is likely that prednisolone inhibited in some way the development of the antigen-antibody complex, as it could be proved in experiments in vitro also (Mannheimer, Reimer, and Windhager, 1954; Steffen, Fessl, and Schnidler, 1957).

From our results we may draw the conclusion that it is advisable to use purified (fractionated) antigens for the demonstration of autoantibodies, because in this way the undesirable cross reactions may be eliminated.

\section{REFERENCES}

Bjørneboe, M., and Krag, P. (1947). Acta path. microbiol. scand., $24,352$.

Bouchier, I. A. D., Rhodes, K., and Sherlock, S. (1964). Brit. med J., 1, 592 .
Dausset, J., and Marchal, G. (1959). 1st International Symposium o Immunopathology, p. 113. Schwabe, Basel.

Dóbiás, G. (1963a). J. clin. Path., 16, 441.

- (1963b). Orv. Hetil., 104, 587.

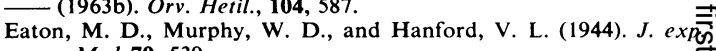
Med. 79, 539.

Findlay, G. M., Martin, N. H., and Mitchell, J. B. (1944). Lance 2365

Gajdusek, D. C. (1958). Arch. intern. Med., 101, 9.

Kühn, H. A., and Weinreich, J. (1964). Dtsch. med. Wscher., 89, 72

Mackay, I. R. (1958). New Engl. J. Med., 258, 185.

$\longrightarrow$, and Gajdusek, D. C. (1958). Arch. intern. Med., 101, 30.

Mannheimer, E., Reimer, E. E., and Windhager, E. (1954). Wien. Zी inn. Med., 35, 493.

Miles, J. A. R. (1946). Brit. J. exp. Path., 27, 25.

Muschel, L. H., Simonton, L. A., Wells, P. A., and Fife, E. H., Jr(1961). J. clin. Invest., 40, 517.

Olitzki, L., and Bernkopf, H. (1945). J. infect. Dis., 77, 60

Osztovics, M., and Szutrély, Gy. (1960). Orv. Hetil., 101, 1481.
Rissel, E., Steffen, C., and Wewalka, F. (1957). Wien. klin. Wschro 69,885 .

Scheiffarth, F., and Berg, G. (1950). Klin. Wschr., 28, 349.

$\longrightarrow$, Frenger, W., and Brichzy, W. (1955). Ibid., 33, 445.

Schneider, W. C., and Hogeboom, G. H 123

Steffen, C., Fessl, F., and Schnidler, H. (1957). Acta haemat (Basel) 17,81

Szécsey, G., Dóbiás, G., and Porgányi, M. (1963). Z. Immun.-Forsch. 125,81 .

- - - and - (1964). Orv. Hetil., 105, 399.

Vorlaender, K. O. (1952). Z. ges. exp. Med., 118, 352.

(1955). Disch. Arch. klin. Med., 202, 253.

Wiedermann, G., Doerner, M., and Miescher, P. A. (1964). Schweito med. Wschr., 94, 257. 